\title{
EDITORIAL
}

\section{AS TÉCNICAS DE IMUNOPEROXIDASE NO ESTUDO DA ETIOLOGIA DAS DOENÇAS INFECTUOSAS E PARASITÁRIAS}

$\mathrm{Na}$ década de 40 , quando a Imunologia se organizava febrilmente como ciência e surgiam os primeiros conhecimentos sobre os mecanismos imunológicos de algumas doenças, apareceram na literatura os primeiros relatos de Albert $\mathrm{H}$. Coons sobre a marcação de anticorpos com produtos fluorescentes e sua utilização na deteç̧ão de antígenos no tecido. Em 1950 , Coons ${ }^{10}$ completou seus estudos sobre essa promissora tecnologia, inaugurando a Imunocitoquímica, um novo campo dentro da Imunologia. De posse dessa nova ferramenta, a Imunologia desvencilhou-se das fronteiras vasculares e estendeu-se definitivamente aos tecidos e seus componentes. Assim, ampliou-se qualitativamente o arsenal da Patologia que, até então, se utilizava apenas de colorações inespecíficas para a análise histopatológica. Como consequiência, a definição da etiologia de muitas doenças, até então avaliadas só empiricamente, passou a ser apenas uma questão de tempo.

Apesar de toda a contribuição da imunofluorescência, essa técnica mostrou-se bastante limitada para um grande número de finalidades, em virtude de várias características próprias do método, entre elas: distorções da imagem emitida decorrentes de dificuldades de ajuste da iluminação do campo e da absorção luminosa pelo conjugado; limitações do anticorpo conjugado quanto à solubilidade e reatividade especifica; o curto período de tempo permitido à análise adequada das preparações em virtude do decaimento rápido da fluorescência emitida. Ademais, devem ser citados fatores que interferem com a especificidade do método, como autofluorescência, reação do tecido com o fluurocromo não conjugado, além da impossibilidade de se usar tecidos fixados adequadamente, processo indispensável para preservação da morfologia. Acrescentam-se, finalmente, os equipamentos relativamente caros necessários para a montagem apropriada de toda a tecnologia.

A partir da década de 60 , desenvolveu-se a utilização de enzimas marcadoras ligadas ao anticorpo covalentemente ou através de pontes naturais, ao invés dos compostos fluorescentes. $O$ sítio da enzima era, posteriormente, revelado através de método histoquímico com o auxilio de um número relativamente grande de produtos coloridos que se depositam no local da reação. Convém lembrar de dois requerimentos básicos inerentes a determinada enzima que se deseja

Recebido para publicação em 15/12/87

\section{IMMUNOPEROXIDASE TECHNIQUES IN THE STUDY OF THE ETIOLOGY OF INFECTIOUS AND PARASITIC DISEASES}

Albert $\mathrm{H}$. Coons was one of the first to report on the labeling of antibodies with fluorescent dyes and their utilization to the detection of antigens in tissues. That happened in the fourties when Immunology was getting feverishly organized as a science and the first initial reports on immunologic pathogenesis of some diseases appeared in the literature. In 1950 Coons $^{10}$ finished his studies with this promising technology, getting started the Immunocytochemistry, a new branch of Immunology. With this new tool Immunology went beyond the blood vessel frontiers and reached the tissues and their components. The old non-specific histopathologic stains were improved with more sophisticated resources. As a consequence the definition of the etiology of several diseases by then, only known empirically, was simply a matter of time.

In spite of the great contribution of immunofluorescence, this technique is too limited by its own peculiarities. Some of them are: distortions of the image due to difficulties in the adjustment of the field illumination and light absorption by the conjugate as well as specific reactivity and solubility of the antibody conjugate; the short length of time useful for adequate analysis of the preparation due to the quick decay of the emitted fluorecence. These are also some factors which interfere with the method such as auto-fluorescence and reaction of the unconjugated fluorochrome with the tissue, and impossibility of its use with fixed tissue which is critical for the morphology preservation. Besides, equipments of high cost are required.

Since the sixties, enzymes instead of fluorescent conjugates were linked covalently or through natural bridges to the antibody. The enzyme site was subsequently shown by histochemistry with the help of a large number of dyes deposited at the reaction site. It should be remembered two basic requirements related to each enzyme used as a marker: the enzyme reaction should be insoluble and visible. One of the enzymes used for this is peroxidase, which reacts with its substrate, the hydrogen peroxide. This results in the oxidation of its heme prostetic group. A "primary complex" is created. In the presence of a third substance, an electron donator, the "primary complex" is dissociated and regenerates peroxidase to its reduced state. The oxidated electron donator polimerizes and precipitates at the reaction site. The 3,3-diaminobenzidine is one of the most commonly used substrates for the his- 
utilizar como marcador em histoquímica: o produto da reação enzimática deve ser insolúvel e visível. A peroxidase, uma das enzimas mais utilizadas para essa finalidade, reage com seu substrato, o peróxido de hidrogênio, resultando na oxidação de seu grupo prostético heme e formando um "complexo primário". $\mathrm{Na}$ presença de uma terceira substância doadora de elétrons, o "complexo primário" dissocia-se regenerando a peroxidase a seu estado reduzido e liberando o doador de elétrons oxidado que se polimeriza e precipita-se no local da reação. Uma das substâncias mais utilizadas para a deteç̧ão histoquímica da peroxidase é a 3,3-diaminobenzidina, primeiramente utilizada com esse objetivo em 196612. A diaminobenzidina oxidada forma um polímero intensamente colorido (marrom escuro) e altamente insolúvel, podendo as preparações histológicas ser desidratadas em álcool, diafanizadas em xilol, montadas em bálsamo ou equivalente e examinadas posteriormente. Essas propriedades da diaminobenzidina transformaram a reação de peroxidase em uma das mais confiáveis em histoquímica.

Dois métodos têm sido usados amplamente em imunocitoquímica tendo como desfecho comum a revełação da peroxidase como acima descrito. Primeiro, o método do anticorpo primário livre e o secundário marcado com a enzima e que chamaremos de "imunoperoxidase indireta", como já tem sido designado, porque se processa em dois estágios à semelhança da imunofluorescência indireta. Segundo, o método que utiliza anticorpo não marcado e se processa em três estágios, sendo o terceiro deles constituído pelo complexo "peroxidase-antiperoxidase" ou, abreviadamente, PAP. Esse complexo é constituido geralmente por duas moléculas de imunoglobulina e três de peroxidase ligadas por pontes naturais. $O$ método do PAP foi aplicado pela primeira vez por Sternberg e cols ${ }^{20}$ e foi ilustrado com a demonstração especifica do Treponema pallidum. Nesse método, o anticorpo primário é livre e produzido na mesma espécie animal que o anticorpo acoplado à peroxidase. $\mathrm{O}$ anticorpo secundário serve de ligação entre o anticorpo primário e ao integrado no complexo PAP. O anticorpo primário policlonal pode ser substituído por anticorpo monoclonal com as devidas modificações adaptativas na cascata.

Trabalhos comparativos têm demonstrado, tanto a nível de microscopia óptica como de microscopia eletrônica, a superioridade do método do anticorpo não marcado (PAP) sobre o marcado, principalmente em relação à sensibilidade e à qualidade das preparações 7131722 . Apesar dessas diferenças, ambos os métodos têm sido empregados com êxito na identificação de antigenos teciduais os mais diversos, entre eles agentes biológicos causadores de doenças, principalmente antígenos virais, bacterianos e alguns parasitas de difícil identificação pelos métodos convencionais 368910 . tochemical detection of peroxidase ${ }^{12}$. After oxidation diaminobenzidine becomes highly insoluble and dark brown. The precipitate can go through alcohol and xylene and be mounted with paraffin sections as usual. The preparation is kept permanently. These diaminobenzidine properties made the peroxidase reaction one of the most reliable histochemical procedures. Two methods are widely used in immunocytochemistry. Both have in common the peroxidase development as described above. One of them is the previously named "indirect immunoperoxidase" because it goes through two steps like indirect immunofluorescence. The primary antibody is free and the secondary is labeled with peroxidase. The second method utilizes unlabeled antibody and goes through three steps. The third step is the antiperoxidase complex or, for short, PAP. This complex is usually made up of two molecules of immunoglobulin and three of peroxidase conjugated by natural bridges. Sternberg et al ${ }^{20}$ were the first ones to use the PAP method. They used it to demonstrate specifically the Treponema pallidum. In this method the primary antibody is free and harvested from the same animal species as the one connected to the peroxidase. The secondary antibody serves as a connection between the primary antibody and the PAP complex. The policlonal primary antibody may be replaced by a monoclonal antibody with the modifications required for the reaction.

The better sensitivity and preparation quality with the unlabeled antibody (PAP) when compared to the labeled one has been shown by light and electron microscopy 7131722 . In spite of these differences both peroxidase methods reliably detect a great number of tissue antigens from disease caused by biological agents mainly viral, bacterial and some parasitic ones, usually difficult to identify by the conventional techniques 368919 . This utilization is also encouraged by the fact that the routinely formalin-fixed tissues are perfectly adequate for these techniques. The intracellular parasites are the ones most difficult for diagnosis by routine methods. Their typical morphology is not always well preserved and they may not be adequately identified.

High dilutions of the primary antibodies are needed to minimize non-specific binding (as it happens with policlonal antibodies). As usual with any immunocytochemical reaction positive and negative controls are also needed. One of them, for instance, uses absorption of the specific antibody with the corresponding antigen. Great care should be exercized with the treatment of the tissues by fixatives. Usually, failure to demonstrate some antigens actually present in the tissues is the consequence of the kind of fixative utilized or the way the fixative is employed. The immunocomplex and immunoglobulin antigen presentation usually is masked by the usual fixation methods. In 
Editorial. Barbosa, Alfredo $J A$. As técnicas de imunoperoxidase no estudo da etiologia das doenças infectuosas $e$ parasitárias. Revista da Sociedade Brasileira de Medicina Tropical 21: 1-6, Jan-Mar, 1988

Esta utilização é encorajada também pelo fato de que, na maioria das vezes, tecidos fixados rotineiramente em formol, prestam-se adequadamente para a aplicação destas técnicas. Os parasitas de localização intracelular estão entre os que oferecem maior dificuldade para o diagnóstico, através de métodos histológicos rotineiros, tendo em vista que sua morfologia tipica nem sempre está bem preservada ou nem sempre pode ser identificada.

Na padronização das técnicas de imunoperoxidase necessita-se de anticorpos primários que possibilitem altas diluições, a fim de minimizar as ligações inespecificas (no caso de anticorpo policlonal) e de controles positivos e negativos comuns a qualquer reação imunocitoquímica, entre eles a pré-absorção do anticorpo especifico pelo antígeno homólogo. Todo cuidado deve ser dispensado ao tratamento dos tecidos pelas soluçōes fixadoras. O fracasso na demonstração de determinados antígenos presentes no tecido deve-se freqüentemente ao tipo de fixador utilizado ou ao modo como se utiliza determinado fixador. Como exemplo, a apresentação antigênica das imunoglobulinas e imunocomplexos costuma ser afetada pelas fixações usuais. Nesses casos, o pré-tratamento dos cortes com enzimas proteoliticas, como a tripsina, pode ser útil ${ }^{18}$. Em nosso laboratório, sempre que possivel, testamos diversos tipos de fixação do tecido durante os testes de padronização do método do PAP para identificação de determinado antigeno, inclusive parasitário. Os dois fixadores líquidos que usamos rotineiramente são o formol salino tamponado, a 10\%, e Bouin com 1,5 a $2,0 \%$ de ácido acético. Amostras do mesmo tecido são, também, congeladas em Freon imerso em nitrogênio líquido, liofilizadas, incluidas em parafina diretamente (sem fixação) e após fixação em vapor de paraformaldeído e de benzoquinona cristalizada; técnicas essas utilizadas em outros laboratórios de histoquimica. Em geral, apenas para a identificação grosseira de parasitas no tecido, os fixadores líquidos têm se revelado suficientes. Entretanto, os resultados podem variar entre diferentes laboratórios, considerando que soluções e anticorpos utilizados não são os mesmos. Exemplificando, Conley e cols ${ }^{9}$ demonstraram pelo PAP Toxoplasma gondii em tecidos formalizados enquanto que, em nosso laboratório, tecidos de camundongos com toxoplasmose experimental fixados em formol, não apresentaram imunorreatividade satisfatória em relação ao parasita; já nas amostras fixadas em Bouin ou liofilizadas o resultado foi excelente.

A identificação de várias espécies de Leishmania pela imunoperoxidase indireta ${ }^{16} 19$ e pelo PAP4 tem sido relatada em tecidos formalizados. Entretanto, independentemente do método empregado, os antisoros testados deram resultado positivo somente em altas concentrações (títulos até 160) o que resulta em niveis relativamente altos de coloração inespecifi- those cases the pre-treatment with proteolytic enzymes such as tripsin, may be usefull ${ }^{18}$. In our laboratory whenever possible we test several kinds of tissue fixation whenever the PAP method for some antigen is standardized. The routinely used liquid fixatives are $10 \%$ buffered saline formaldehyde and Bouin's solution with 1.5 to $2 \%$ acetic acid. Samples of the same tissue are also freeze-dryed after frozen with liquid nitrogen cooled Freon. The samples are embedded in paraffin either without fixation or after fixation in paraformaldehyde or crystaline benzoquinone vapour. The se techniques have also been utilized by other histochemistry laboratories. Usually liquid fixatives have been satisfactory for tissue identification of parasites. However, the results may vary among different laboratories considering that the solutions and the antibodies employed are not the same. For example, Conley et $\mathrm{al}^{9}$ have demonstrated by PAP method Toxoplasma gondii in formalized tissue. In our laboratory mice tissue with experimental toxoplasmosis processed with the same fixatives did not show satisfactory immunoreactivity to the parasite; the results were excelent with sample either fixed with Bouin or freeze-dryed.

Formalin fixed tissues have been used for the identification of several species of Leishmania by indirect immunoperoxidase ${ }^{16} 19$ and by PAP4. However, with both methods positive results were found only with high antiserum concentrations (titers up to 160) which cause unacceptably high levels of nonspecific staining and interfere with the quality of the preparations. These low anti-Leishmania titers of sera do not seem to be due to fixative action on the parasite or to the low afirnity of the tested antibody: with freedryed tissue the titers rarelyu go beyond 320 (Barbosa, A.J.A et al. unpublished data). The same antisera used to detect $T$. cruzi reveals amastigotes with dilutions above 1:2000, with several strains 4 .

The difficulties found in the identification of T. gondii and Leishmania in routine histological reactions are also found with $T$. cruzi especially during chronic Chagas' disease. It's not usual for the parasites to have typical, well preserved ${ }^{15}$ and easily identifiable cysts. To improve the identification of $T$. cruzi amastigotes, indirect immunoperoxidase ${ }^{11}$ and $\mathrm{PAP}^{3}$ were proposed. Policlonal rabbit antibodies were used with both techniques. The primary antibody titer was too low with the first technique. The dilution ranged from 1:40 to 1:320. On the other hand PAP showed good results with titers between 1000 and 1600 . Positivity was found up to 1:4000 with PAP technique. Subsequently, it was found that in macerated fetal tissue the PAP method worked satisfactorily. It identified cysts of amastigotes which, due to autolysis, were, not diagnosed in routine hematoxylin and eosin staining 15 . 
ca, prejudicando a qualidade das preparaçōes. Estes títulos baixos dos soros anti-Leishmania parecem não ser resultado da ação dos fixadores sobre o parasita, nem do grau de afinidade dos anticorpos testados, uma vez que, em tecidos liofilizados os titulos raramente ultrapassam a 320 (A.J.A. Barbosa e cols: dados não publicados) e, a utilização destes mesmos anti-soros para detectar o $T$. cruzi revela amastigotas com títulos superiores a 2.000 , em relação a diversas cepas 4 .

As dificuldades encontradas para a identificação do $T$. gondii e Leishmania, em preparações histológicas rotineiras, ocorrem também como $T$. cruzi, principalmente na fase crônica da doença de Chagas. Nem sempre os amastigotas formam ninhos intracelulares característicos que sejam facilmente identificados em preparações convencionais e nem sempre os parasitas apresentam morfologia típica e bem conservada ${ }^{15}$. No sentido de facilitar a identificação de amastigotas do T. cruzi foram propostas a utilização da imunoperoxidase indireta ${ }^{11} \mathrm{e}$ a do PAP ${ }^{3}$. Embora em ambas as técnicas propostas tenham sido utilizados anticorpos policlonais produzidos em coelhos, a primeira apresentou positividade com título muito baixo do anticorpo primário, ou seja, 40, reagindo até um máximo de 320. Por outro lado, o método do PAP deu bons resultados com títulos entre 1.000 e 1.600 , apresentando positividade até 4.000 . Verificou-se, posteriormente, que em tecidos de feto macerado, o método do PAP funcionou satisfatoriamente e permitiu a identificação de ninhos de amastigotas que não puderam ser diagnosticados em preparações coradas pela hematoxilina e eosina (HE), em virtude do avançado grau de autólise ${ }^{15}$. Igualmente, tecidos fixados rotineiramente e conservados por décadas em parafina, prestaram-se muito bem à identificação de ninhos de amastigotas pelo PAP $^{5}$. Esta constatação abre as portas para a execução de pesquisas imunocitoquímicas retrospectivas em tecidos incluidos em parafina e arquivados por longo tempo.

O método do PAP, aplicado aos tecidos fixados em formol, revela formas amastigotas íntegras principalmente pela reatividade dos antígenos presentes na membrana celular ${ }^{3}$. Pode, entretanto, revelar fragmentos de parasitas ou parasitas parcialmente digeridos e depositados no interior de macrófagos, como observado em baço de camundongos imunes que receberam cargas elevadas de formas sangüineas do $T$. cruzi e que apresentaram, simultaneamente, queda da parasitemia ${ }^{14}$. Para detectar particulas antigênicas menores do $T$. cruz $i$, provavelmente o material formalizado não se presta, embora exo-antígenos difundidos a partir do parasita, às vezes, possam ser demonstrados. A parede interna dos ninhos de amastigotas em células musculares lisas apresenta forte imunorreatividade pelo PAP ${ }^{3}$ o que poderia ser conseqüência da impreg-
Routinely fixed tissues kept for decades in paraffin were adequate for the identification of amastigote cysts with PAP5 ${ }^{5}$. This discovery opened the doors to retrospective research with paraffin embedded tissue kept for a long time.

The PAP method applied to formalin fixed tissue shows intact amastigotes especially by the reactivity with the cell membrane antigens ${ }^{3}$. It also may demonstrate parasite fragments or partially digested parasites phagocytosed by macrophages. This has been shown with spleens of immunized mice receiving large doses of blood forms of $T$. cruzi and developing low parasitemia ${ }^{14}$. Probably formalin fixed tissue is not adequate for detecting minute amounts of $T$. cruz $i$ antigenic particles. However, exo-antigens difused from the parasite may sometimes be demonstrated. The internal wall of amastigote cysts in smooth muscle cells has strong immunoreactivity with PAP ${ }^{1}{ }^{3}$. It might be caused by local impregnation of parasite antigens. The strongly immunoreactive material in macrophage and giant cells cytoplasms both by indirect immunoperoxidase ${ }^{19}$ and PAP 21 in formaldehyde fixed tissue infected with Leishmania has been suggested to be of parasitic origin.

There remains no doubts that the PAP method is far superior the routine methods of staining, and also for the quantitative studies of the tissue parasitism. Well preserved and somewhat large amastigote cysts may be easily identified both by routine stains as well as by PAP. However, small nests, with few amastigotes, (less than 20) or sometimes 1 or 2, may be identified only with great difficulty in routine histologic sections even by the most experimented observer. The difficulties are compounded when the standard parasite morphology is not evident. Because such small nests are usually found in the acute and sub-acute phase of the disease $^{2}$, the PAP method, in spite of its complexity, is the one of choice in these situations. This explains, at least in part, the results of the comparative study between PAP and H.E. in three chronic chagasics. Two of them presented with abundant parasites (relapsing or subacute disease) mainly detected by the PAP ${ }^{5}$. In the third case, with scant parasites, in a hundred sections one cyst was found with H.E. and two with PAP; therefore, the difference was not significant. This result, allied to others from studies in progress, help us believe that in chronic chagasics with scant parasites the yield is similar either with H.E. or with PAP when looking for amastigotes. With a small number of sections the immunocytochemical method, which is complex and expensive, is not justified. In these cases the conventional methods are adequate and PAP should be applied only to those sections serial to the positive or suspected sections, either to better study the parasite bearing cell or to confirm the antigenic kind of the parasite. On the other hand, the systematized application of PAP is recommended when there are clues 
nação local de antígenos parasitários. $\mathrm{O}$ encontro de material fortemente imunorreativo no citoplasma de macrófagos e de células gigantes tanto pela imunoperoxidase indireta ${ }^{19}$ como pelo PAP 21 , em tecidos infectados por Leishmania e fixados em formol, foi sugerido como sendo antígenos parasitários.

Não restam dúvidas de que o método do PAP é bem superior aos métodos rotineiros de coloração também para estudos quantitativos do parasitismo tecidual. Ninhos de amastigotas, relativamente grandes e bem conservados, podem ser identificados com facilidade, tanto através de colorações rotineiras como pelo PAP. Entretanto, ninhos pequenos, apresentando na secção histológica poucos amastigotas $(<20)$ ou, às vezes, apenas um ou dois, só com muita dificuldade podem ser identificados em preparações histológicas convencionais, mesmo pelo observador experimentado. As dificuldades aumentam quando a morfologia padrão do parasita não é aparente. Como estes ninhos menores são mais encontrados na fase aguda da doença e na chamada forma subaguda ${ }^{2}$, o método do PAP, apesar de ser mais complexo, é recomendável. Isto explica, pelo menos em parte, os resultados do estudo comparativo entre o PAP e o HE em très chagásicos crônicos dos quais dois apresentavam rico parasitismo (doença reativada ou subaguda) detectado principalmente pelo PAP5 5 . No terceiro caso, com parasitismo escasso, em uma centena de cortes encontrou-se 1 ninho pelo HE e 2 pelo PAP, portanto, não apresentando diferença importante. Esse resultado, somado a outros de trabalho em andamento, nos leva a acreditar que, em chagásicos crônicos, com escasso parasitismo, os resultados da procura de amastigotas pelo $\mathrm{HE} e$ pelo PAP são semelhantes, quando se analisa um pequeno número de cortes, não se justificando a utilização do método imunocitoquimico, mais complexo e dispendioso, apenas com este objetivo. Nesses casos, aconselha-se o procedimento da pesquisa pelos métodos convencionais, aplicando-se a técnica do PAP nos cortes seqüenciais aos positivos ou suspeitos, tanto para estudar melhor a célula parasitada como para confirmar a natureza antigênica do parasita. Por outro lado, caso haja indicios de que o parasitismo seja mais freqüente que o usual, recomenda-se a aplicação do PAP de forma mais sistematizada. Evidentemente que a decisāo a ser tomada vai depender das disponibilidades técnicas do local de trabalho.

A aplicação de método imunocitogênicos modernos está presentemente galgando seus primeiros degraus no terreno da Patologia Tropical. A associação desses métodos qualitativos a nível de microscopia óptica e eletrônica, com outros das áreas de Microbiologia, Imunologia e Bioquímica promete responder muitas questões, hoje em aberto, sobre o complexo relacionamento parasito-hospedeiro de importantes doenças infectuosas e parasitárias. that the parasitism is more common than usual. It is evident that this decision will depend on the resources available to the researcher.

The modern immunocytochemical methods are, reaching the first steps in the study of the Tropical Diseases. The association of these qualitative methods at light and eletronic microscopy levels, with others in the areas of Microbiology, Immunology and Biochemistry promises answers to many unsolved questions related to the complex relationship between host and parasite from important parasitic and infectios diseases.

\section{REFERENCES}

1. Almeida HO, Martins E, Franciscon JU, Teixeira VPA, Barbosa AJA, Gobbi H, Reis MA. Caracteristicas das células parasitadas pelo Trypanosoma cruzi na parede da veia central das supra-renais de chagásicos crônicos. Revista da Sociedade Brasileira de Medicina Tropical 19:227-231, 1986.

2. Andrade ZA, Andrade SG. Forma subaguda da miocardite chagásica. Revista do Instituto de Medicina Tropical de São Paulo 5:273-280, 1963.

3. Barbosa AJA. Metodo imunocitoquimico para identificação de amastigotas do Trypanosoma cruzi em cortes histológicos de rotina. Revista do Instituto de Medicina Tropical de São Paulo 27:293-297, 1985.

4. Barbosa AJA, Costa CA, Ramirez LE, Tafuri WL, Raso P, Mayrink W. Antibodies against Leishmania species react more strongly with Trypanosoma cruzi amastigotes than with the homologous amastigotes. An immunocytochemical study. Memórias do Instituto Oswaldo Cruz 81 (suppl): 131, 1986.

5. Barbosa AJA, Gobbi H, Lino BT, Lages-Silva E, Ramirez LE, Teixeira VPA, Almeida HO. Estudo comparativo entre o método convencional e o método da peroxidase-antiperoxidase na pesquisa do parasitismo tissular na cardiopatia chagásica crônica. Revista do Instituto de Medicina Tropical de São Paulo 28:91-96, 1986.

6. Barbosa AJA, Queiroz DMM, Mendes EN, Rocha GA, Lima Jr. GF, Oliveira CA. Immunocytochemical identification of Campylobacter pylori in gastritis and correlation with culture. Archives of Pathology \& Laboratory Medicine, 112:523-525, 1988

7. Burns J. Background staining and sensitivity of the unlabelled antibody-enzyme (PAP) method. Comparison with the peroxidase labelled antibody sandwich method using formalin fixed paraffin embedded material. Histochemistry 43:291-294, 1975.

8. Burns J. Immunoperoxidase localization of hepatitis B antigen (HB) in formalin-paraffin processed liver tissue. Histochemistry 44:133-138, 1975.

9. Conley EK, Jenkins KA, Remington JS. Toxoplasma gondii infection of the central nervous system. Use of peroxidase-antiperoxidase method to demonstrate $T o$ xoplasma in formalin fixed, paraffin embedded tissue sections. Human Pathology 12:690-698, 1981.

10. Coons AH, Kaplan MH. Localization of antigen in tissue cells; improvements in method for the detection of antigen by means of fluorescent antibody. Journal of Experimental Medicine 91:1-13, 1950. 
11. Croker BP, Kuhn RE. Immunohistochemical detection of Trypanosoma cruzi in tissues of mice with experimental Chagas' disease. Histochemistry 77:195-200, 1983.

12. Graham RC, Karnovsky MJ. The early stages of absorption of injected horseradish peroxidase in the proximal tubule of mouse kidney: ultrastructural cytochemistry by a new technique. Journal of Histochemistry and Cytochemistry 14:291-296, 1966.

13. King BF. Localization of transferrin on the surface of the human placenta by electron microscopic immunocytochemistry. Anatomical Record 186:151-159, 1976.

14. Kretlli AU, Barbosa AJA, Galvão LMC, Orsini MLP. Antibody-mediated destruction of trypomastigotes (Try) in vivo: Parasite-like debris detected by peroxidase-antiperoxidase (PAP) staining in the spleen macrophages. Memórias do Instituto Oswaldo Cruz 81 (supp1):112, 1986.

15. Lana AMA, Lages-Silva E, Barbosa AJA. Doença de Chagas congênita: avaliaçāo imunocitoquímica do parasitismo em tecidos de feto macerado. Revista da Sociedade Brasileira de Medicina Tropical 19:95-98, 1986.

16. Livmi N, Abramowitz A, Londner M, Okon E, Morag A. Immunoperoxidase method of identification of Leishmania in routinely prepared histological sections. Virchows Archives Pathological Anatomy 401:147-153, 1983.
17. Mason DY, Taylor CR. The distribution of muramidase (lysozyme) in human tissues. Journal of Clinical Pathology 28:124-130, 1975.

18. Mepham BL, Frater W, Mitchell BSL. Use of proteolytic enzymes to improve immunoglobulin staining by the PAP technique. Histochemistry Journal 11:345-357, 1979.

19. Sells PG, Burton M. Identification of Leishmania amastigotes and their antigens in formalin fixed tissue by immunoperoxidase staining. Transactions of the Royal Society of Tropical Medicine and Hygiene 75:461468, 1981.

20. Stemberg LA, Hardy PH Jr, Cuculis JJ, Meyer HG. The unlabelled antibody-enzyme method of immunohistochemistry. Preparation and properties of soluble antigen-antibody complex (horseradish peroxidase-antihorseradish peroxidase) and its use in identification of spirochetes. Journal of Histochemistry and Cytochemistry 18:315-333, 1970.

21. Tafuri WL, Michalick MSM, Dias M, Rios-Leite V, Barbosa AJA, Bambirra EA, Costa CA da, Melo MN, Genaro O, Mayrink W. Optical and electronic microscope studies on the kidneys of dogs with natural visceral leishmaniasis. Memórias do Instituto Oswaldo Cruz 81 (suppl): 52, 1986.

22. Taylor CR. Immunohistologic studies of lymphoma; past, presente and future. Journal of Histochemistry and Cytochemistry 28:777-787, 1980.

Alfredo J. A. Barbosa

Departamento de Anatomia Patológica e

Medicina Legal da Faculdade de Medicina da

Universidade Federal de Minas Gerais,

Belo Horizonte, Brasil 